Trans/Form/Ação, São Paulo,

13: $41-72,1990$.

\title{
KANT E O PROBLEMA DA ORIGEM DAS REPRESENTAÇÕES ELEMENTARES: APONTAMENTOS
}

\author{
Ubirajara Rancan de Azèvedo MARQUES*
}

RESUMO: Trata-se de considerar a origem das representações fundamentais (formas de receptividade e formas intelectuais), face à crítica de Kant às idéias inatas e abstratas.

UNITERMOS: Aquisição originária; aquisição derivativa; "inato"; "abstraído".

"Die erste Frage ist: wie in uns Begriffe entstehen können, die uns durch keine Erscheinung der Dinge selbst bekannt geworden, oder Sätze, die uns keine Erfahrung gelehrt hat."

(KANT, "Rfl. Met."; Nr. 4470)

Nos Prolegômenos, Kant, a respeito do conceito de causa, reprova os "opositores" de Hume, de vez que "absolutamente não alcançaram... o ponto da sua questão":

"Tratava-se apenas da origem desse conceito, não da indispensabilidade do mesmo no uso: fosse aquela apenas descoberta, ter-se-iam então com isso já de si mesmas dado as condições do seu uso e o âmbito no qual ele pode ser válido." (1)

Da resposta à questão da origem dos conceitos de que se serve a metafísica, isto é, da resposta à generalização do "problema humeano", ou, ainda, dos resultados da "decomposição do nosso inteiro conhecimento a priori nos elementos do conhecimento puro do entendimento" (2) decorrem as "condições" de uso dos mesmos (o quando e como da sua habilitação ao conhecimento) e o "âmbito" unicamente no qual é garantida a sua validade (restrição à possibilidade da experiência).

Não se trata agora, propriamente, de argumentar em favor de que os conceitos da metafísica - ou as formas da sensibilidade - têm mesmo sua sede numa atividade pura

* Departamento de Filosofia da Faculdade de Filosofia e Ciências - UNESP - 17500-Marılia-SP. 
do espírito. Não se trata de resolver como se o problema soasse: donde?, mas, partindo de algum modo do mesmo, trata-se de responder à questão: como? Como fazer que conceitos puros refiram-se tais à experiência; como fazer para esta manter-se em dado irredutível? (3)

Em que pese a eventual fragilidade da periodização que subjaz à visão kantiana da história da filosofia-dogmatismo e ceticismo-, tipos a que sucede, menos como progresso que limitação, o criticismo da razão pura (4), note-se que, com isso, o problema dos limites no uso do entendimento caminha ao lado de um terreno previamente demarcado. Isto é: a consolidação do lugar destinado ao criticismo exige, deste, a eqüidistância daqueles. Ora, tal como nas Meditações de Descartes não se procede à destruição de "todas" as "antigas opiniões", nem é necessário examiná-las "cada uma em particular", mas se trata apenas de indicar os "princípios" (5) que as fundamentam, também com respeito a Kant, creio, sua tripartição da história da filosofia pode servir-nos de figura metodológica que, ao reduzir assim dois milênios de especulação, busca sobretudo realçar as bases nas quais se apóia a história dela.

Com efeito, se se tem em mira a superação das metafísicas, o julgamento da legitimidade delas como ciência, a questão dos princípios que nortearam sua trajetória é a condition sine qua non de toclo o processo. Numa palavra, se dogmatismo e ceticismo são verso e anverso da mesma falida moeda, compreende-se que formem o referencial teórico perante o qual deve impor-se o tribunal da Crítica. Entre o desespero cético e o conformismo dogmático, a prestabilidade ontológica do intelecto crítico confere uma objetivação virtual a tudo o que (lhe) aparece. Voltando-se originalmente ao real do puro aparecer, o entendimento crítico o enforma e converte em aparecer puro, dele fazendo sua própria realidade objetiva. Por conseguinte, em nível da problemática do conhecimento, vale dizer, segundo o que, de modo imediato, já era posto como tarefa a cumprir no Essay de Locke (6), e conforme as linhas de força que realçam a polêmica da epistemologia seiscentista-mas ainda a da setecentista -, a esse nível, portanto, a Crítica da Razão Pura, consideradas a Estética e a Analítica transcendental, torna-se agora a instância em que devem ser julgados tanto o inatismo quanto o abstracionismo das idéias. Entretanto, o problema geral da origem dos conceitos não deve, aqui, ser tratado como o da sua aquisição; ou, melhor, o aspecto lógico deve ser considerado à parte do psicológico, pois o primeiro é o que unicamente importa na esfera de uma investigação transcendental. Pode-se mesmo dizer que uma certa vaniloqüência na polêmica do inatismo dá-se justamente em função do psicologismo que eia abriga, sendo pois irrelevante a questão de quando obtemos as representações que propiciam o conhecimento: se antes, após ou ao nascermos. Tais questões, elas só se aplicam à mera posse; não, portanto - e todavia é preciso - à investigação de como, um e outro partido, podem ambos alcançar a objetividade (7). Conseqüentemente, entender-se a investigação kantiana como se o a priori significasse uma prioridade temporal é tão-só repor em jogo o que, decerto, aos olhos de Kant pertencia ao passado (8). Poder-se-ia também dizer que cada uma das três fontes originárias do conhecimento (9) reproduz a composição fundamental do mesmo: parte sensível, parte intelectual. A operação coordenativa da sensibilidade requer, por um lado, a afecção externa (10), e, por outro, a 
determinação transcendental (ou afecção interna) através das categorias; o entendimento, por sua vez, o estof o a que, de si mesmo, ele se aplique; já a imaginação a existência de um múltiplo a ser diretamente subsumido ao esquema que ela produz. O lado intelectual dessa bipartição aloja-se na índole sintético-originária da mente humana; já o sensível, na empírica do objeto que é "dado". Tal reflete o ponto de vista de Kant comoleitor da história da filosofia, repartida entre o dogmatismo e o ceticismo; mas, em nível da polêmica contemporânea no campo da origem do conhecimento, essa bipartição ressoa as posturas do inatismo e do abstracionismo das idéias, as quais, porque ambas conservadas, impõem a tarefa da sua mútua limitação.

Contudo, o problema da origem das formas puras do espaço e do tempo, como também o da origem dos conceitos puros do entendimento, é, em nível de articulação da Crítica, uma etapa já antes percorrida. Na fronteira entre os assim chamados períodos "pré-crítico" e "crítico", ou seja, com a Dissertação de 1770, a questão é diretamente enfocada; e, com ela, de pronto af astada a origem inata ou empírico-abstrata das futuras Anschauungsformen e Gedankenformen.

Em verdade, não se pode, sequer de uma só obra de Kant, afirmar que ela contenha um discurso polêmico centrado nas questões do inatismo ou do abstracionismo das idéias. Se se pode então falar de algo assim como de "Kant e o inatismo", por exemplo, a primeira regra de prudência a observar é a de não fazer dos escritos onde o tema é abordado momentos do mesmo debate que, entre tantos, houve de ocupar a atenção de um Locke ou de um Leibniz.

A Crítica da Razão Pura não vê no inatismo um inimigo a combater. Nem mesmo a "Estética transcendental" concede-lhe um só momento de atenção-nem mesmo: pois, afinal, a Dissertação ocupara-se dele justamente para negar a origem inata dos conceitos do espaço e dó tempo. A Crítica-embora a Dissertação já o fizesse (11)-volta-se em primeiro lugar para a polêmica entre os que defendem - como dirá a Reflexão $n^{\circ} 4673-$, quer a "realidade subsistente" do espaço e do tempo (os newtonianos), quer a "aderente" (osleibnizianos) (12). De resto, as próprias questões que efetivamente inauguram a Estética só fazem apontar os mesmos personagens: Newton, Leibniz e o próprio Kant (13). Também com relação aos conceitos intelectuais não há, no tocante à origem, diferença marcante da Dissertação (14) à Crítica (15). Dir-se-á talvez que a Crítica da Razão Pura, menos que propriamente negar o inato, retira-o do ambiente em que ele se encontrava, transferindo-o, por assim dizer, da metafísica teológica (ou da psicologia supostamente racional) (16) para a crítica do conhecimento. Noutras palavras, a questão do conhecimento, tal como posta na Crítica, resultará numa desteologização dos elementos envolvidos na tarefa de resolvê-lo. A esse respeito, Hume jú adiantara o passo.

Com efeito, o autor do Tratado da natureza humana refere-se à disputa sobre "whether there be any innate ideas, or whether all ideas be derived from sensations and reflexion". $\mathrm{O}$ tom do enfoque parece aludir a um modo pretérito (se não ultrapassado) de colocar a questão: "For 'tis remarkable, that the present question concerning the precedency of our 
impressions or ideas, is the same with what has made so much noise in other terms, when it has been disputed..."(17). Também na Investigação sobre o entendimento humano, texto conhecido de Kant, o mesmo tema volta à baila, numa crítica a Locke, merecendo a nota que encerra a "Seção II" (Da origem das idéias). Nela, Hume afirma: "If by innate be meant, contemporary to our birth, the dispute seems to be frivolous; nor is it worth to enquire at what time thinkingbegins, wheter before, at, or after our birth". Da mesma forma, pouco antes dizia: "If innate be equivalent to natural, then all the perceptions and ideas of the mind must be allowed to be innate or natural, in whatever sense we take the latter word, whether in oppositin to what is uncommon, artificial ormiraculous" (18). Todas as percepções seriam então "naturais", opondo-se a: "incomum", "artificial" e "milagroso" (19). Conseqüentemente, o "inato" seria: não-"milagroso" enquanto "a miracle is a violation of the laws of nature" (20); não-"incomum" enquanto ninguém está privado dele (21); não-"artificial" enquanto não surge da educação e das convenções humanas (22). Mas, se assim for - como afirmava Hume da oposição de "natureza" a "milagre" na suposta naturalidade dos "sentimentos" de "vício" e "virtude": "we make no very extraordinary discovery" (23). De que então terá valido o esforço de tanta polêmica? Se ela carece de importância, cumpre ao menos indicar e dissolver o erro que a nutriu. Ora, a essa identificação de "inato" com "natural" subjaz a própria ambigüidade na etimologia da palavra. Com efeito, innatus, particípio de innascor (nascer em ou sobre), onde o prefixo in - relaciona-se com a preposição in, é o mesmo que "nascido em ou sobre", "natural"; por outro lado, in-natus, adjetivo, onde o prefixo in - relaciona-se com a negação ne, é o mesmo que "incriado" (24). Também "idéia" não pode ser qualquer uma de nossas percepções, sensações, paixões ou pensamentos, como queria Locke (25), pois no tocante à origem o mesmo termo admitiria os significados opostos de "inato" e "adquirido", caso se tratasse, por exemplo, respectivamente da "paixão entre os sexos" (26) ou da idéia de "um ser infinitamente inteligente, sábio e bom" (27). A "paixão sexual" é "uma afecção evidentemente implantada na natureza humana" (28), enquano a "idéia de Deus" provém da "reflexão sobre as operações de nossa própria mente (29). A primeira é inata, mas a outra não. Assim: "But admitting these terms, impressions and ideas, in the sense above explained, and understanding by innate, what is original or copied from no precedent perception, then may we assert that all our impressions are innate, and our ideas not innate". (30) Com isso, evitando anfibolias e rompendo querelas vãs (onde Locke e os escolásticos andaram juntos) (31), o que Hume faz é definir o termo em questão. Expediente asséptico que o autor do Essay relutou em praticar. Por conseguinte, ou as nossas percepções (impressões como idéias) serão "naturais" - pois a fonte comum de ambas é a própria natureza (32) - , nenhuma razão havendo de o empirista polemizar a existência de noções inatas, ou apenas as impressões serão "incriadas", não-derivadas de qualquer representação. Não há tanto um novo sentido de inato, mas a inversão da perspectiva anterior. Se com Hume "inato" = "original" = "impresso", ele é ainda uma representação determinada. $\mathrm{O}$ que de fato ocorre é a desvalorização da polêmica do inatismo. $\mathrm{O}$ inato não representa mais o caráter de uma interferência divina, mas a própria ação da natureza. A crítica de Hume torna-se ainda mais forte justamente porque decorre da aceitação da 
etimologia tradicional do termo, inseparável da densidade teísta conferida a ela pela metafísica clássica.

Portanto, se outrora o inato remetia a uma alma referta de noções implantadas por obra de Deus, remete agora ao fato de o homem encontrar-se à mercê das afecções. Mas a rápida menção de Hume ao problema das idéias inatas, longe de ser um referencial teórico de vulto, parece mais uma concessão de circunstância ao espólio do inatismo, ela própria moldada no espírito da Enlightment.-Como afirma Cassirer: "(...) para Descartes e Malebranche, para Spinoza e Leibniz, a razão é a região das 'verdades eternas', verdades comuns ao espírito humano e ao divino. (...) O século XVIII trata a razão com um sentido novo e mais modesto. Ela não é o nome coletivo das 'idéias inatas' que nos são dadas com anterioridade a toda experiência, e nas quais nos é revelada a essência absoluta das coisas. A razão, longe de ser uma tal possessão, é uma forma determinada de aquisição. (...) (Ela é) a força espiritual radical que nos leva à descoberta da verdade e a sua determinação e garantia. (...) Todo o século XVIII concebe a razão nesse sentido (...) como uma energia, uma força que não se pode compreender plenamente senão em seu exercício e em sua ação". (33)

Tanto quanto Hume, o autor da Crítica não está propriamente a debater a questão específica da proveniência das idéias na perspectiva do inatismo. A recusa do inato surgirá em meio a uma reviravolta no eixo de solução do problema, reaparecendo, assim, a tópica da "revolução copernicana". Do homem duplamente passivo-tendo, de um lado, as afecções da experiência, e, de outro, as noções impressas por obra do Criador - ao sujeito que por si mesmo elabora o conteúdo das impressões sensíveis, a matriz da "metafísica da natureza" não mais se encontra no intelecto intuitivo do "ente originário", mas nas pré-disposições discursivas do ente humano finito (34).

Se se pode então dizer - com o Kant da Dissertação, é certo, mas também com o da chamada Resposta a Eberhard - que há "leis estáveis e inatas" (stabiles et innatas leges), ou que um "fundamento" no sujeito, "que torne possível que as representações pensadas nasçam assìm e não de outra maneira", que "ao menos esse fundamento é inato" (dieses Grund wenigstens ist angeboren), tais asseverações-de resto, amplamente contrabalançadas - pertencem a u m quadro onde o importante é a exclusão do viés inatista como característica primeira dos elementos do conhecimento a fim de salvaguardar-lhes a originária e irredutível diversidade das fontes. Vale notar ainda que, se Kant e Hume podem comungar da mesma opinião em relação a esse ponto, tal ocorre à medida que o autor da "Enquiry", rechaçando uma querela inútil - o que aos olhos de Kant decerto significava o abandono do psicologismo contido nela-, é agora como que o próprio precursor da filosofia transcendental (35). Note-se mesmo que, de modo geral, Kant estará de acordo com a crítica lockeana ao inatismo - à exata medida que esta não diga respeito à aquisição lógica das partes do conhecimento, mas, por assim dizer, só à psicológica (36).

Observe-se, pois, na Dissertação, o fato de o inatismo ser apenas secundariamente evocado, como para enfatizar a distância que o separa do tipo específico de representação em vista. Jamais considerada a fundo, quer fosse por atacá-la, quer por defendê-la, "a 
questão de saber se ambos os conceitos |(espaço e tempo)| sãoinatos ou se são adquiridos" parece apresentar-se em nome da originalidade do percurso esboçado; ou, numa palavra, apenas porque "surge... quase espontaneamente" (37) - suposto que entre aqueles decerto acomodados com a maneira habitual de resolver o problema (38). Mas, por outro lado, importa considerar mais de perto a positividade conferida à chamada lei "lei do espírito", a única coisa que há de propriamente inato na alma do homem (39). Com efeito, trata-se de um "princípio interno da mente" (40) para a coordenação do material sensível, ele próprio indissociado de certas "leis estáveis e inatas" (41). Entretanto, os conceitos originam-se por intermédio de aquisição. Decerto que não se trata de uma aquisição empírica, onde os mesmos seriam abstraídos "a partir da sensação dos objetos" (42); ao contrário, são eles "abstraídos" a partir de "leis ínsitas na mente (atendendo às ações desta por ocasião da experiência)" (43).

Os conceitos de espaço e tempo, pois, constituem os resultados de uma tal aquisição. Não sendo inatos, inata é a capacidade de organizar o múltiplo sensível, precisamente em relações espaço-temporais. Na verdade, são ambos obtidos, quando, por intermédio de tais relações, ef etiva-se o poder inato do espírito. Trata-se assim de uma atividade a ser evocada, e que atua por meio de coordenações espaço-temporais. Mas, posto que a sensibilidade humana é inteiramente receptiva, sua única interferência é sempre a de receber o que de si mesmo nos af eta e por meio disso se cumpre em aparência. Se não houvesse tal instância receptora, isto é, semelhante capacidade (44), jamais haveria o estofo ao qual se aplicassem as categorias do entendimento. Por conseguinte, o caráter operativo da capacidade sensível de conhecimento é todo dependente do objeto que a afeta; sem uma tal presença, por meio da sensação, não há o que a evoque, e, portanto, a faça coordenar. Em contrapartida, a "espontaneidade", ou seja, a faculdade (45) dos atos enformadores, tal significa uma característica peculiar à mente humana, cujo exercício desdobra os conteúdos engendrados por ela mesma.

Em 1770, Kant conquista a distinção-que concerne à essência, não meramente ao grau - entre o sensível e o inteligível, de onde, portanto, os "conceitos intelectuais", não se pode obtê-los por abstração a partir das intuições sensíveis, mas, em verdade, "eles são dados pela própria natureza do entendimento" (46) - e, acrescente-se, "não como conceitos inatos, mas como conceitos abstraídos das leis ínsitas na mente" (47). Como se pode facilmente ver, "dados pela própria natureza do entendimento" equivale a "abstraídos das leis ínsitas na mente"; apenas que, para a primeira expressão, o que importa é a distinção: "sensível"/"inteligível", e, para a outra, a distinção: "inato"/"adquirido". Em ambas, porém, o processo de obtenção dos conceitos intelectuais é o mesmo, ou seja, a abstração. Mas, como previne o próprio Kant, o conceito intelectual é o-que-abstrai (o "abstraente"), não o-que-é-abstraído (o "abstracto") (48). Novamente, tal distinção indica o corte entre o "sensível" e o "inteligível", de forma que o conceito intelectual é então o-que-abstrai-do-sensível, não o-que-é-abstraído-do sensível. Numa palavra, ele não resulta de uma generalização do singular, mas, outrossim, é já obtido como implicando uma universalidade originária, embora careça, para ser adquirido, da ocasião em que a experiência o requisite. 
Se do "tempo" Kant afirma que a sua idéia "não nasce dos sentidos" (49), do "espaço" diz que o seu conceito "não é abstraído das sensações externas" (50). Quanto a este, nota ainda que "o conceito de espaço é uma representação singular que compreende em si todas as coisas, e não uma noção abstrata e comum que sob si as contém". (51) Ora, ao contrário do que ocorre para os conceitos do espaço e do tempo, não se pode, a rigor, quer em nível da Dissertação, quer da Crítica, perguntar sobre se os conceitos intelectuais são do tipo que contêm sob si ou em si; pois, a saber - no que se assemelham ao espaço e ao tempo - , eles não são conceitos de objetos (o que, na Crítica, conduzirá à sua designação como "categorias"). Já os conceitos do espaço e do tempo, conceitos sensíveis, deles se diz que não são do tipo que contêm sob si, justamente porque, assim, só se faz dos conceitos obtidos por abstração, a partir das sensações (conceitos do tipo: o-que-é-abstraído-do-sensível). Mas, quando se diz que são do tipo que contêm em si, tal significa, precisamente, que as partes das quais seriam abstraídos-isto é: espaços e tempos determinados-estão contidas nas representações originárias "espaço" e "tempo", as quais, portanto, unicamente permitem a organização de um objeto sensível nos limites de uma representação espaço-temporal qualquer (52). De resto, pode-se supor que Kant estivesse (parcialmente) de acordo com a crítica de Berkeley às "idéias abstractas"; todavia, os dois sentidos em que aquele distingue o termo "abstracto" (53) não podem equiparar-se aos encontrados por este nos Principles (54).

Convém ainda observar a semelhança que guardam entre si certos textos da Dissertação e da Res posta a Eberhard, confirmados na Crítica, nas Reflexões e Preleções sobre metafísica (55). Trata-se de um período de vinte anos, no qual, como se sabe, constrói-se e perfaz-se o sistema crítico. De resto, não só a doutrina permanece a mesma como é expressa por um vocabulário equivalente - fato que, reconhecida a flutuação semântica do léxico kantiano, não parece de somenos importância. Salvo engano, o primeiro registro dessa teoria aparece na Dissertação. Nela, espaço e tempo são ditos formas originárias, daquele se afirmando que é "dado de modo originário mediante a natureza da mente" (56); deste, que é "primitivo e originário" (57). Assim, a originalidade conceitual do espaço e do tempo, ou o modo específico da sua aquisição, consiste precisamente no serem obtidos, de modo puro, "por ocasião da experiência" (58). Evocada a coordenação para o múltiplo sensível, a ação do espírito efetua-se por meio de relações espaço-temporais, do conjunto destas sendo abstraídos os conceitos de espaço e tempo. Ao nível do modo por que são obtidos, trata-se, pois, de uma simples aquisição por abstração. Todavia, como se trata de algo adquirido $d e$ mim, não, pois, tomado a outrem ou ao que quer que fosse e lhe detivesse a posse, uma tal aquisição é particularmente originária (59). Ainda que Kant só venha a expressar-se em termos de "aquisição originária" e "aquisição derivativa" na Resposta a Eberhard, parece-me que já na Dissertação a perspectiva é fundamentalmente a mesma, apenas diferindo quanto à clareza da exposição (60). Assim, a "aquisição originária" é uma "ação" (Handlung) pela qual se adquire a "representação" de algo "que antes não existia ainda de modo algum, por conseguinte, que não pertencia a coisa alguma antes desta ação"; representação que, portanto, só após ser originariamente adquirida (através de uma "ação") passa a pertencer à consciência por meio dos poderes ou faculdades que a exercem. Tem-se pois, com isso, a recusa, por assim dizer, do inatismo tout court, e, ao mesmo tempo, a admissão 
(reelaborada, contudo) do primado empirista da acquisitio dos conceitos. É preciso, ademais, notar que o termo de 'aquisição originária' ("acquisitio originaria"/ursprüngliche Erwerbung) concentra em si as faces opostas do problema cuja solução ele pretende exprimir. Uma vez posto que os elementos do conhecimento são todos adquiridos (erworben), ou que de modo algum são inatos (angeboren) à mente humana, é necessário assinalar a natureza de uma tal aquisição, ou seja, sua total independência da aquisição empírica e dos dados da experiência imediata (61). Com efeito, "a forma das coisas no espaço e no tempo", bem como "a unidade sintética do múltiplo em conceitos" são ambas adquiridas de modo originário, sendo que, para tanto, só se requer de "inato", respectivamente, o "fundamento formal... da possibilidade de uma intuição do espaço", por exemplo, e "as condições subjetivas da espontaneidade do pensamento"-em suma, "um fundamento... que torne possível que as representações pensadas nasçam assim e não de outra maneira" (62).

Contudo, é evidente que num certo sentido "categorias" e "formas de intuição" já estão dadas, mas em outro não. Estão dadas não porque sejam inatas, mas sim porque, não havendo mais relevância na questão da sua origem, parte-se do fato que elas se encontram no sujeito. Mas esse fato poderia ser um mero fato psicológico, quer elas resultassem da experiência, quer fossem inatas. Assim, todo o esforço da dedução objetiva é no sentido de mostrar a transcendentalidade das Gedanken - e Anschauungsformen. Da condição de um presumido fato psicológico elas passam à de um fator transcendental provado.

Kant nunca se ocupou também em demonstrar o número e a identidade das "formas de intuição", como fez com as "formas de pensamento". Todavia, quanto a estas, o que lhe preocupou foi sua Entdeckung, não seu Entspringen.

Donde e como se originam as categorias, quer em geral, quer em particular, cada qual um conteúdo-eis um ponto que não concerne à investigação. Damo-nos simplesmente conta delas refletindo sobre as operações do intelecto, por ocasião da experiência. Mas isso equivale a dizer que são virtualmente inatas? Apesar do reiterado emprego de um vocabulário leibniziano, a solução de Kant (se para ele havia problema) a respeito da origem das representações elementares é de úma ponderável sutileza em relação a Leibniz. Não há, pois, representações (elementares ou não) virtualmente inatas; há sim, virtualmente inato, um "fundamento" (Grund) para a produção e aquisição originárias (por ocasião da experiência) das Gedanken-e Anschauungsformen, produção e aquisição inteiramente devidas à atividade espontânea do sujeito, apenas "desperto" pelas sensações, o qual fundamento, ele próprio, não é atualizável, sendo-o porém aquelas Formen puras.

De resto, é provável que Kant, com respeito às representações, aceitasse o primado empirista conhecido como esse est percipi, tanto mais não seja por negar o papel de mera ocasião de descoberta consagrado por Leibniz à sensibilidade. Esta não é mais a oportunidade de atualização de representações já dadas, mas a ocasião para que uma atividade subjetiva espontânea efetue as representações elementares. Apenas que a consciência dessas representações não é afeita à sensibilidade receptora, mas à espontaneidade agente. Passa-se então do esse est percipi ao esse est effici. 
Entretanto, referindo-se à expressão: "devem... por si próprios ser claros e certos" (müssen... vor sich selbst klar und gewiss sein) (63), Vaihinger a considera, concordando com Erdmann (64), como sendo "uma característica do conceito cartésio-lockeano de idéias inatas, que no aperfeiçoamento (Fortbildung) kantiano dessa doutrina não cabe mais de modo algum (gar nicht mehr hineinpasse)" (65). Lembremos também que Vaihinger, decerto por interpretar a "grande luz" de 1769 como resultado dos Nouveaux Essais de Leibniz (66), considera que o "a priori" de Kant (ao menos na Estética) "possui grande parentesco com o inato (mit dem Angeborenen grosse Verwandschaft besitze)", e que o mesmó "é no essencial idêntico ao inato (ist... mit dem Angeborenen im Wesentlichen identisch)" (67). Ora, se por um lado Kant aceita (explicitamente em 1770) o binômio "inato"f"adquirido" - rechaçando o primeiro termo para fixar-se no segundo, mas opondo (explicitamente em 1790) o par "originário"/"derivativo" - , recusa por outro conceder-lhe maior importância enquanto mero referencial de origem (68). Se a representação inata (o "Grund" de que fala a Resposta) é pura, nem por isso a representação a priori é inata-mas, precisamente, sendo pura a priori é originariamente adquirida! E, aqui, não vejo como identificar: "aquisição originária" e "inatismo virtual". Se não se deve aquiescer apenas à diferença nominal ("aquisição"/"inatismo"), mas sobretudo considerar os termos que especificam a realidade das representações ("originário"/"virtual"), tal procedimento nada acrescenta além da fixação de um "parentesco" meramente frouxo, a saber, o de que ambos sãopuros ou não-empíricos; pois, se para cada um deles ("originário" e "virtual") o elemento da efetivação (respectivamente: da "aquisição" e da "atualização") é o mesmo, ou seja, a ocasião fornecida pela experiência, o contraste é posto à medida que o contributo empírico é diferentemente valorado. Numa palavra, onde para um a experiência dá o estofo ou a matéria do conhecimento (sem o que a instância enformadora carece de "realidade objetiva"), para outro fornece apenas o meio de expor o conteúdo da verdade eterna, isto é, a própria conformidade (na relação que a verdade-adaequatio-manifesta) do nosso intelecto com o divino (69).

Cohen também refletiu acerca do "inato" em Kant ou da pertinência em aproximá-lo do a priori crítico. Diz ele em Kants Theorie der Erfahrung: "Quando Kant começou a investigação sobre a origem e o âmbito do conhecimento humano, a filosofia estava há mais de um século ocupada com a questão de se nossas representações são inatas ou adquiridas" (70). Partindo de semelhante legado, Kant "superou a disjunção pré-crítica: inato ou adquirido" (71); com isso, a "determinação de 'inato' " pertence à "versão pré-kantiana do problema da doutrina do conhecimento (Erkenntnislehre)" (72). Todavia, "originalmente ele queria salvar (retten) tanto o a priori quanto o inato" (73). Essa tese é avançada no intuito de explicar uma eventual suspeita de "contradição" por afirmações de Kant na Resposta a Eberhard, supostamente incompatíveis com declarações da Crítica (74). Assim, Cohen afirma: "Poder-se-ia encontrar nesse ponto uma contradição com o aspecto agora mesmo captado da 'Crítica'; pois, segundo este, as 'disposições (Anlagen) para o pensar' não devem estar imediatamente 'implantadas (eingepflantzt) junto com nossa existência”" (75). Ora, a citada passagem da Crítica (76) opõe-se a um "caminho intermediário" (Mittelweg) entre os dois únicos possíveis "dos quais pode ser pensada uma concordância necessária da experiência com os conceitos 
de seus objetos": o caminho por uma espécie de "generatio aequivoca" e a chamada "epigênese da razão pura" (77). Trata-se assim de combater um suposto "sistema da pré-formação da razão pura" onde houvesse uma "concordância" acabadasobrenaturalmente garantida - entre nós próprios e "as leis da natureza nas quais se processa (fortläuft) a experiência" (78). Porém, a filosofia crítica não admite lugar para a concórdia natural entre "consciência" e "realidade", como algo de que passivamente nos daríamos conta sem a garantia de sua produção. Mas Cohen pensa haver uma "hesitação" (Schwanken) da parte de Kant, detectável na "contradição" esboçada entre a Resposta e a Crítica. Ora, mas o "fundamento" existente no sujeito-que, "ao menos" ele, é "inato" (79)- não se confunde com uma disposição de pensamento para o mero refletir de um acordo prévio com as leis da natureza; ele é uma simples capacidade para recepções espaço-temporais e pensamentos por categorias, originariamente adquiridos. $\mathrm{O}$ que vêm determinadamente a ser "intuições" e "conceitos puros" não se encontra de antemão sabido, como tampouco dadas estão as leis da natureza. Todavia, Cohen prossegue: "Assim, na tese de habilitação (Habilitations schrift): 'de mundi sensibilis et intelligibilis forma et principiis', ele designou o tempo como 'subjectiva conditio', per naturam mentis humanae necessaria. Também nessa obra (Schrift), em verdade, já é resolvida, no sentido da 'Crítica', a questão de se o conceito é connatus ou acquisitus. Mas a 'lex naturae', não obstante, é designada como inata. $\mathrm{O}$ a priori crítico está aqui ainda completamente ausente. $\mathrm{Na}$ 'Estética transcendental', em verdade, o a priori já se encontra no sentido transcendental. Mas deve ser questionado se a 'Introdução', na qual o conceito é definido, não foi redigida mais tarde que aquela. Tal como espaço e tempo são ensinados na 'Estética transcendental', não prevalece ainda, firme e penetrante, o mais aguçado sentido do a priori, superador de todo o dogmatismo. $\mathrm{O}$ espaço aparece, por isso, sempre e apenas como a priori, pois ele é o modo necessário de representação, isto é (falsamente!), o modo inato de representação". (80)

Dado que com a "Introdução" da Crítica o "a priori" é apenas o "modo necessário de representação", ele é "falsamente" identificado com "o modo inato de representação", ainda que, depois, a Estética contenha uma "exposição transcendental" do espaço e do tempo (formas a priori da sensibilidade), e, portanto, considere-o de um ponto de vista que supera o inatismo. A leitura de Cohen identifica "modo necessário" e "inato" de representação; ou, simplesmente, "necessário" e "inato". Bastaria, de fato, recordar que, para Leibniz, as "verdades necessárias" ou "de razão" têm o seu estatuto a partir do pressuposto metafísico de que foram impressas na alma, onde, portanto, estão inatas. Decerto que, tal como definido, o "a priori" pode ser tomado como similar ao "inato" - até porque este nunca é empregado na Crítica; mas, para além do que ambos possam ter em comum, há um "fundamento" cuja especificidade - o ser "inato" - não pode confundir-se com o "a priori". Com ef eito, só a partir da Resposta a Eberhard torna-se possível alcançar a positividade do "inato", e, portanto, a demarcação de suas fronteiras.

Não é porque pretenda "salvar" a ambos que Kant indica um lugar a cada um, mas porque certos pontos devem ser ocupados, cujas funções são adequadamente designadas por aqueles termos. O que fica com a Resposta definitivamente afastado é a possibilidade de 
se confundirem os papéis de cada qual. Por conseguinte, quando se nomeia uma "representação" ("intuição"; "categoria"; "esquema"; "princípio"; "idéia") ou "faculdade" ("sensibilidade"; "imaginação"; "entendimento"; "razão") de (pura) a priori, o que se indica (conforme a tradição racionalista) é a mera autonomia perante a experiência. Já ao se perguntar sobre que é ou como se tem uma "representação" (pura) a priori, então é preciso considerar o modo da sua aquisição (conforme a tradição empirista), e, portanto, o fundamento inato que subjaz a ela. Mas se se indaga da função de uma "representação" ou "faculdade" (pura) a priori, em tal caso há que ter presente o ponto de vista transcendental (conforme o criticismo) de onde ela opera. Com isso, só há equivocidade entre "inato" e " $a$ priori" quando não se leva em conta a função daquele, prescrita na Resposta; caso contrário, o"apriori" é o mero sobrenome das Erkenntnisvorstellungen, por onde se atesta a sua nobreza de estirpe. De resto, é só com Kant que se pode primeira e apropriadamente falar em ambos os termos de "inato" e "a priori" como conceitos distinguidos com rigor e precisão. A índole racionalista com que o sistema crítico é em parte banhado não favoreceu a que procedessem dessa forma as doutrinas dogmáticas submersas nela, nas quais, portanto, aqueles termos se confundem.

\section{Tornar-se-á agora claro o contexto da "Introdução" da Crítica:}

"Nenhuma dúvida há de que todo o nosso conhecimento começa com a experiência; pois, caso contrário, por onde a faculdade de conhecimento deveria ser despertada para o exercício, tal não ocorresse através de objetos que movem nossos sentidos, e em parte de si mesmos efetuam representações, em parte põem em movimento nossa atividade intelectual para compará-los, conectá-los ou separá-los, e assim elaborar o estofo bruto das impressões sensíveis para um conhecimento dos objetos que se chama experiência? Segundo o tempo, portanto, nenhum conhecimento precede em nós a experiência, e todo ele começa com esta.

Mas, ainda que todo o nosso conhecimento surja (anhebt) conı a experiência, nem por isso todo ele se origina (entspringt) precisamente da experiência". (81)

Temos assim que todo o nosso conhecimento, em sentido estrito, provém sempre e só do que, separadamente, é o específico de cada uma de ambas as faculdades que o compõem: intuição (sensibilidade) e conceito (entendimento).

Todavia, ao perceber-se a sintese que Kant opera entre o dogmatismo e o ceticismo (para empregar suas próprias expressões), ou idealismo e empirismo, é preciso, sobretudo, observar a ocorrência de uma alteração no modo de conceber a efetividade do conhecimento. Para Locke, como para Berkeley e Hume também, o conteúdo último e propriamente dito do conhecimento provém apenas de uma única fonte - a experiência -, como "sensação", "idéia" ou "impressão"; mas, por outro lado, igualmente para Leibniz, onde esse mesmo conteúdo, todo ele, provém de nós próprios ou da nossa alma, à maneira de nọções inatas, criadas e impressas por Deus na mônada sem janelas. Para Kant, porém, o conhecimento é a reunião (Vereinigung) da intuição e do conceito, ambos entre si heterogêneos e pertencentes a faculdades distintas. Por outro lado, se os conceitos do 
entendimento se encontrassem impressos em minha mente-já, pois, de antemão me pertencendo - , não os poderia eu próprio engendrar, ou seja, produzi-los ao refletir sobre a elaboração da matéria. Mas, em verdade, são primeiramente obtidos na síntese do múltiplo a priori. Há tão-só uma predisposição inata do entendimento humano que, excitada pelo estofo da sensibilidade, corresponde a este por meio da ação produtora da categoria. Logo, esta é a obra de um intelecto puro, evocada a partir da experiência. Trata-se assim de formas-de-pensamento para um objeto (indeterminado) sensível.

Ora, mas se "deve haver razão" nas ciências, "algo nelas tem de ser conhecido a priori" (82); e, portanto, no âmbito de uma "metafísica da natureza" os elementos que perfazem o conhecimento científico dos objetos têm de exibir uma origem pura. Entretanto, "como posso esperar um conhecimento a priori de objetos, por conseguinte uma metafísica, à medida em eles nos são dados aos nossos sentidos, por conseguinte, a posteriori?" (83)

A resolução do problema exige de quem o persiga uma reflexão particular, filosófico-transcendental. Semelhante percurso deve levar-nos à descoberta do sujeito do conhecimento, cuja atividade perfaz a elaboração dos "objetos de experiência possível" (84). Trata-se menos da manutenção de um par de opostos da metafísica clássica que da sua mais completa subversão. A inelutabilidade do fluxo perceptivo tem agora o contraponto de uma atividade espontânea, que só precisa ser "desperta" para empreender o que lhe cabe na produção do conhecimento. Dizer que "das coisas conhecemos a priori apenas o que nós próprios colocamos nelas" (85) é atentar para o fato de que o conhecimento (puro) é produzido através da reflexão; pois, a saber, ele é o próprio ato da enformação por meio do qual ligamos o múltiplo dado alhures, tornando-nos conscientes dele como da objetividade por nós constituída enquanto tal (86). Todavia a Verstandestätigkeit não atua sobre o "estofo bruto das impressões sensíveis" da forma como pretenderia o investigador de uma reflexão ingênua. Se o faz, é a prol de "um conhecimento dos objetos que se chama experiência". Entretanto, tais objetos já não podem valer como objetos da experiência comum (87), que não opera a distinção entre o-que-aparece-a-nós e o-que-é-em-si; porém, são eles agora objetos de conhecimento, produtos da reunião, não mais entre a sensibilidade confusa e o entendimento distinto (88), mas sim do "múltiplo da intuição pura a priori" com as categorias que sobre ele incidem (89). Da mesma forma, a "experiência" como "conhecimento dos objetos", ou reconhecimento objetivo do múltiplo sensível, é o resultado da circunscrição da cientificidade possível para o entendimento humano; assim considerada, ela se torna o território da objetividade ou da "validade objetiva" das fontes de conhecimento-numa palavra, o horizonte da verdade transcendental.

A singularidade da empresa kantiana aponta, pois, para a reconsideração do significado tradicionalmente associado a termos como: sujeito; objeto; experiência; conhecimento, etc (90). Se há uma sensibilidade empírica, um entendimento que confere generalidade aos conceitos de cuja matéria ocupa-se a experiência, uma lógica que não distingue o conteúdo das proposições, há também, sobretudo, uma sensibilidade pura (91), um entendimento puro donde promanam conceitos igualmente puros - cujo próprio "conteúdo" (Inhalt) vem portanto do intelecto (92) - , uma lógica transcendental que fixa as formas de ligação entre 
as representações numa unidade a ser expressa em juízos, etc (93). Mas não se pense, entretanto, haver duas sensibilidades, duas lógicas afeitas a dois entendimentos; nem mesmo, a rigor, quando se trata de assinalar a unicidade fundamental do conhecimento, convém lembrar demasiado a partição da sensibilidade e do entendimento, da Estética e da Analítica. Ora a partição que se observa é apenas o fenômeno da "decomposição" (Zergliedenung) do que sempre se experimenta unitariamente, ou seja, o próprio conhecimento; ademais, não há um conhecimento bruto em seguida tornado puro pela ação das faculdades responsáveis por ele: há tã̉o-só um conhecimento, proveniente da experiência imediata, o qual, no entanto - sem o sabermos de pronto-, há de ser a reunião da intuição e do conceito, elementos originários de duas faculdades da alma, distintas em gênero e grau... - a qual reunião (a saber, na doutrina do esquematismo) como que coroa, ạo nível da elaboração (inversamente, pois), o que sempre é dado como uno através da percepção. Desse modo, a questão da possibilidade de um conhecimento necessário e universal dos objetos enquanto fenômenos exige logo a fixação de uma atividade coordenadora do material receptado através da sensação. Mas, para que o próprio dado seja recebido de modo puro, a mera receptividade dos fenômenos já é tarefa de formas puras da sensibilidade. $O$ sujeito do conhecimento exibe em sua estrutura de consciência as condições de possibilidade unicamente através das quais ele é passível de ser afetado por objetos da experiência. Tais condições ou intuições puras contêm "princípios das relações" (94) dos fenômenos, isto é, compõem o modo por que os mesmos se hão de apresentar ao sujeito (95), sendo assim a própria razão pela qual o objeto de conhecimento é simplesmente fenomênico (96).

Envolta, quer pela naturalidade com que a todos se apresentava, ainda em 70, o problema da origem inata ou empírico-abstrata das representações, como também, em 90 , pela forte e ruidosa incompreensão demonstrada por Eberhard (onde o a priori crítico tornara-se próximo do inatismo virtual), a reação de Kant, matizada 'que tenha sido (porque, com a Dissertação, não lhe concernia o tema mais do que a outros, mas, com a Resposta, era a própria Crítica que ele tinha de pôr a salvo), é convictamente unívoca: "A Crítica não aceita, em absoluto, representações incriadas ou inatas; pertençam à intuição ou aos conceitos do entendimento, ela as considera todas como adquiridas". (97)

A oposição de Kant aos modelos em debate sobre a origem do conhecimento apresenta, assim, diferentes motivações, ambas, porém, ocasionando um mesmo recato quanto ao vigor e extensão do envolvimento. A postura assumida-clara e firme no que tange à negação do inatismo e do empíreo-abstracionismo das representações, obscura e por vezes frouxa no que se refere à tese da "aquisição originária" - contém ainda um definitivo contraste frente à posição de Leibniz, não tanto, porém, devido à maneira pela qual o autor do sistema da "harmonia preestabelecida" compreendera especificamente o "inato" (isto é: como virtualidade), mas em razão do âmbito no qual este mesmo atuava (isto é: conforme um modelo de conhecimento em que a experiência é a mera causa ocasional). $\mathrm{O}$ próprio Kant terá compreendido o "inato" como disposição virtual. Todavia, a experiência que o atualiza, longe de apenas cumprir esse papel, forma agora um contributo de cuja presença o conhecimento não pode prescindir. A questão, afinal, reporta-se ao fato de que o "inato" 
em Kant não é mais o próprio conhecimento (a própria representação determinada), mas apenas a base de elaboração para um material sensivel. Decerto que a experiência possui ainda o caráter instigador de antes, mas, agora, concomitantemente ao estatuto de colaboradora (material) do conhecimento.

\section{NOTAS}

Todas as citações de obras de Kant têm por base a chamada Edição da Academia (Akademie-Ausgabe) na seguinte variante: "Unveränderter photomeckanischer Abdruck der Textes dervon der Preussischen Akademie der Wissenschaften 1902 begonnenen Ausgabe von Kants gesammelten Schriften. Walter de Gruyter \& Co., Berlin, 1968. "Esta edição compreende os textos dos nove primeiros volumes da edição original da "Academia" ("Erste Abteilung: Kants Werke (Bd. I-IX)"), seguidos de dois tomos com as notas que lhes correspondem ("Anmerkungen der Bände I-V"/"Anmerkungen der Bände VI-IX"). Para os textos restantes seguiu-se a edição original da Academia, a partir do décimo volume. Exclusivamente para a Crítica da Razão Pura optou-se pela edição de W. WEISCHEDEL: "Immanuel Kant: Werke in zwölf Bänden. Suhrkamp Taschenbuch Verlag, Frankfurt am Main, 1974 (Bd. III-IV). Para a Crítica adotou-se o procedimento habitual nas citações: "A" designando a primeira edição (1781), "B" a segunda (1787). Para os textos latinos de Kant mencionou-se a transposição adotada; para os textos em alemão as traduções são minhas.

1-49, p. 258-9; Cf.: 49, p. 324; 41, A 57, B 81-2, onde, precisamente, a "origem", o "âmbito" e a "validade objetiva" dos conhecimentos puros dos objetos caracterizam "a idéia de uma ciência do conhecimento puro do entendimento e da razão", a saber, a "lógica transcendental".

$2-41$, A 64, B 89.

3-Cf.: 74, t. II, p. 23: "Il y a des concepts à priori. Nous n'avons pas le droit de demander pourquoi il y a de tels concepts à priori et non pas d'autres. Kant nous renvoie pour cela à l'onganisation déterminée de notre raison. La seule question légitime est donc: Comment sont-ils possibles?" (Cf. 41, A 95-96); 49, p. 318; 41, B 145-6)

4-47, p. 261-4. - Cf.: 49, p. 360; 38, p. 226-7; 51, (Nr. 5645); p. 293; "(...) entre o dogmatismo e o ceticismo está o modo médio e unicamente legítimo de pensar do criticismo"; 36, p. 66;72, Bd.1, p. 25-8;38-9(Anm. 1); 78, p. 1-33 (a respeito da obra de Willich, Vaihinger é demasiado categórico em só afirmar: "Ohne Werth."... (cf. 72, Bd. 1, p. 20))

$5-18$, p. 85 . 
6-Cf. 7, p. 3: "Quando, no 'Prefácio' à primeira edição, Kant nomeia como programa de sua 'Crítica da Razão Pura' a determinação das fontes, do âmbito e dos limites 'da mesma, mas tudo a partir de princípios', então ele repete a fórmula programática do Essay de Locke, e o 'mas' se volta precisamente contra esta obra, cuja edição corrigida é o texto de 1781".

7-Cf. 60, IV. Bd. (1801), I. Abtheil, p. 14-5.

8-Cf. 62, I, p. 77-80; 74, t. II, p. 25.

9-Cf. 41, A 94. - Locke já dizia das "fontes" donde "surgem" as idéias; cf. 58, p. 104: "These two |("Our Senses" ("SENSATION"); "the Perception of the Operations of our own Minds" ("REFLECTION"))| are the Fountains of Knowledge, from whence all the "Ideas" we have, or can naturally have, do spring".-Cf. 41, A 50, B 74 ("zwei Grundquellen des Gemüts"); A 15, B 29.- Acerca do caráter primário de tais "fontes originárias" - que "não podem ser derivadas de nenhuma outra faculdade do espírito" (cf. 41, A 94) - , cf.: 44, p. 513 ("Que se deva tornar compreensível a possibilidade das forças fundamentais (Grundkräfte) é uma exigência completamente impossível; pois elas justamente se chamam forças fundamentais porque de modo algum podem ser derivadas de uma outra, isto é, ser compreendidas."); 500; 502; 509; 510-52, p. 371.

$10-$ Cf. 72 , Bd. 2, p. 34-55.

$11-$ Cf. $45, \S 14,5 ; \S 15$, D. -Cf. trad., p. 38-9-45, 391.

12-Cf. 41, A 39-41, B 56-8.

13-Cf. 41, A 23, B 37-8. -Cf. 62, I, p. 132-6.

$14-$ Cf. $45, \S 8$.

15-Cf. 41, A 65-6, B 90-1.

16-Excusado dizer do complexo relacionamento entre teologia, ciência e filosofia nos séculos XVII e XVIII. Com respeito a Kant, porém, creio ser no texto: "O único argumento possível para uma demonstração da existência de Deus", onde, anteriormente à Crítica, melhor se capta o universo de pensamento em que ele se achava, cu jo espírito desde então o impelia à recusa do inatismo. Cf.: 36, p. 103-4; 106; 
107; 109-12; 119-21; 143-4. - Decerto que, relativamente ao "Beweisgrund", as próprias leis necessárias da natureza estão na dependência imediata da vontade do Criador; enquanto, na Crítica, parte-se apenas do fato que elas são para o encontro das condições subjetivas da sua possibilidade.

17-34, p. 7. - Cf. 34 , p. $72 ; 84$.

$18-33$, p. 22.

19-Cf. 34, p. 474-5, onde os mesmos sentidos da palavra "natureza" eram examinados, embora noutra ordem: "If 'nature' be oppos'd to miracles (...)"; "But 'nature' may also be opposed to rare and unusual (...)"; "But 'nature' may also be opposed to artificial (...)".

$20-33$, p. 114.

21-Cf. 34, p. 474.

$22-$ Cf. 34, p. 483.

$23-34$, p. 474.

24-O uso que Locke faz do "natural" dá margem à prudência de Hume; cf. 58, p. 48, 52. 54, 59. ("by a natural and original Impression") 60, 62, 64, 66, 67. ("natural tendencies imprinted on the Minds of Men"); 73, 75. ("There is a great deal of difference between an innate Law, and a Law of Nature; between something imprinted on our Minds in their very original, and something that we being ignorant of may attain to the knowledge of, by the use and due application of our natural Faculties.") - Sobre a identificação entre "natural" e "original". cf.: 34, p. 415; 458; 473.

$25-33$, p. 22.

$26-33$, p. 22.

27-33, p. 19.

$28-34$, p. 481. 
29-33, p. 19.

$30-33$, p. 22.

$31-33$, p. 22.

$32-32$, p. 42; 44: "(...) all our ideas, or weak perceptions, are derived from our impressions, or strong perceptions, and that we can never think of any thing which we have not seen without us, or felt in our own minds. This proposition seems to be equivalent to that which Mr. Locke has taken such pains to stablish, 'viz. that no ideas are innate'. Only it may be observed, as an inaccuracy of that famous philosopher, that he comprehends all our perceptions under the term of idea, in wich sense it is false, that we have no innate ideas. For it is evident our stronger perceptions or impressions are innate, and that natural affection, love or virtue, resentment, and all the other passions, arise immediately from nature. I am perswaded, whoever would take the question in this light, would be easily able to reconcile all parties. "; 68; 70.

33-9, p. 28. -Cf.: 10, II, p. 199-201; III, p. 92-105; 15, p. 20-6; 28, p. 43-64; 13, p. 47: "A superstição do inato não poderia ser mais eficazmente combatida e refutada do que através da característica dos conceitos fundamentais como categorias, como modos de manif estação do juízo. O conceito fundamental, portanto, não consiste num resultado, mas numa ação"; 76, p. 358; 75, p. 31-2; 69, p. 89-90; 92; 94;-Não obstante o juízo de Cassirer, sobre que, no século XVIII, a razão não é mais "o nome coletivo das 'idéias inatas' (...) nas quais nos é revelada a essência absoluta das coisas..." pode-se presumir que por vezes reaparecessem ainda certas formulações em vias de serem ultrapassadas - como, por exemplo: 55, p. 106; "(...) gehören die Geometrischen und Chronometrischen Wahrheiten mit unter die ewigen unveränderlichen Wahrheiten." (cf. 41, A XII: "nach ihren |(von der Vernunft)| ewigen und unwandelbaren Gesetzen") - Sobre a polêmica do inatismo no século XVIII, cf., por exemplo, os testemunhos de: 21, Tome Premier, p. 26: "Les idés innées des premieres vérités, défendues pa: Descartes \& Leibnitz, \& qui ont élevé des disputes si vives \& si subtilement discutées parmi les métaphysiciens de ce siecle, ont puisé leur origine dans Platon, source féconde des vérités les plus sublimes pour un esprit attentif." (cf., sobre a obra de Dutens: 30, p. 22-52); 71, p. 338: "Foi evidentemente um equívoco entre ele |(Leibniz)| e Locke - como nem tudo, embora a maior parte - o que subjazeu em seu conflito sobre as idéias inatas, e exatamente assim se passou no conflito de Locke com Descartes"; Bd. II, p. 545. - Por outro lado, cf. a distinção feita por Baumgarten entre o "inato" e o "infuso", isto é, entre o "natural" e o "sobrenatural": 4, p. 102: "As faculdades da.alma que alcançam um grau bastante alto de desenvolvimento são aptidões; a repetição freqüente de atividades de um mesmo gênero, ou, levando-se em conta sua diferença 
específica, semelhantes, é o exercício; é pois pelo exercício que se desenvolve as aptidões da alma. As aptidões da alma que não dependem do exercício mas somente da natureza são ditas inatas (são as disposições naturais); as que dependem do exercício são ditas adquiridas; nomeia-se infusas as aptidões que concernem às faculdades do conhecimento"; já a respeito do uso dos termos: "inato", "adqurido" e "natural", cf. p. 114; 121; 131; 132; 135; 136; 142.

34 - Cf., por exemplo, a correspondência entre Leibniz e Clarke, onde ainda é bastante intenso o vínculo das representações do espaço e do tempo com a problemática teológica.

35-Cf. 49, p. 257-261.

36-Cf. 41, A 86-7, B 118-9.

37-45, p. 406; trad., p. 67-8.

38-Cf.: 57, Bd. V; p. 67; 92; 98, acerca da preguiça intelectual com a aceitação de certo inatismo; 52, p. 331;36, p. 120-1; p. 121: "O célebre exemplo de Newton não pode assim servir de pretexto à confiança preguiçosa para despender um recurso precipitado a uma disposição imediata divina ("(auf)eine unmitelbare göttliche Anstalt") para um esclarecimento conforme o gosto filosófico.") (cf. 52, p. 330 ("(auf) einer besonderen göttlichen Anstalt")); 39, p. 407; 37, p. 131;-Observe-se, na referida passagem desta carta, a ocorrência dos adjetivos: "eingepflantzt" ("gewisse eingepflantzte Regeln zu urtheilen") (p. 131) e "pflantzt" ("..und Begriffe, die Gott schon...in die Menschliche Seelen pflantzte") (p. 131), através da crítica de Kant à pré-formação dos conceitos (cf.: 52, p. 320; 35, p. 196; 41, B 167: "eingepflantzten subjectiven Nothwendigkeit" (cf. 11, p. 102); 49, p.319; "(...) uns diese Naturgesetze ursprünglich eingeptflantzt habe."; 46, p. 26: "Uma necessidade implantada (Eine eingepflantzte Nothwendigkeit) não provaria a necessidade."); da mesma forma, cf.: 48, p. 406: "Tendentia appetitus insiti..."; 45, p. 393; "lex quaedam menti insita"; p. 395: "(...)non tanquam conceptus 'connati', sed e legibus menti insitis... ", em que o termo "insitus" (cuja forma verbal significa: "implantar" ( no alemão: "einpflanzen"); "plantar" ( no alemão: "pflantzen"); "enxertar") terá ocorrido, para a "Nova dilucidatio", num contexto ainda influenciado por Leibniz, e, para a "Dissertatio", ao menos como eco da presença deste na orientação filosófica de Kant. - A respeito da problemática que envolve o inatismo de Descartes, o de Leibniz e o que há de referente a um tal em Kant, cf.: 11, p. 1; 8, t. II; fasc. 1, p. 72; 25, p. 9-50; 66 , p. 161-73; 63, p. 175-90; 1, p. 83-98; 70, p. 61-2; 16, p.61; 63; 75; 77; 17, II, p. 352 (observe-se o uso da expressão: "à leur occasion ", em referência a "órgãos dos sentidos"); 19, III, p. 807; 2, p. 43-5; 64, p. 19-38; 65, p. 51-62. - De resto, a afirmação 
da proximidade entre Leibniz e Kant no que concerne ao "inato" consta de várias interpretações: cf.: 5, p. 34; 67, p. 157; 163; 73, p. 104-10; 195-7; 68, p. 98, n. 31; p. 102, n. 43; 71, Bd. I, p. 87-8: "Nossas representações de coisas corporais externas e esses próprios objetos são de natureza tão heterogênea quanto o mármore do qual é feita uma estátua e o corpo humano que a estátua representa". Mas já Condillac terá feito essa mesma provável alusão a Leibniz: cf. 15, p. 21: "Representou-se a alma como uma pedra sobre a qual tinham sido gravadas diferentes figuras e acreditou-se explicar claramente falando em idéias ou imagens gravadas, impressas, marcadas na alma". Já Cohen, comentando o contraponto dogmático ("ainda que todo o nosso conhecimento sur ja com a experiência, nem por isso todo ele se origina precisamente $d a$ experiência") ao adágio empirista ("nenhuma dúvida há de que todo o nosso conhecimento começa com a experiência") da "Introdução" da Crítica (cf. 41, B 1), afirma: 11, p. 44: "Onde pois é antes de tudo dada a matéria? Onde se originou o próprio a posteriori com que começa todo o nosso conhecimento? É | o conhecimento| aproximadamente como o mármore antes de receber uma forma?"

$39-45$, p. 406 ; trad., p. $67-8 .-$ Cf. 45 , p. 401; trad., p. 60.

$40-45$, p. 393; trad., p. 60.

41-45, p. 10-1-trad., p. 60 .

$42-45$, p. 406 ; trad., p. 68.

43-45, p. 395; trad., p. 48. - Cf. 41, A 57, B 81 ("Handlungen des reinen Denkens").

$44-$ Cf. $57, \S 1$.

45-Cf. 57, § 1.

$46-45$, p. 394; trad., p. 46.

$47-45$, p. 395; trad., p. 48.

$48-45$, p. 394; trad., p. 46.

$49-45$, p. 398; trad., p. 56. 
$50-45$, p. 402; trad., p. 61.

$51-45$, p. 402 ; trad., p. 62 .

52-Cf.: 45, p. 394; trad., p. 46; 53, p. 190-1; 35, p. 131; 42, p. 95; 50 (Nr. 2865); p. 552; (Nr. 2869); 50, p. 553; 50, (Nr. 2876); 555-6.

53-Cf. 45, p. 405/trad., p. 66-7.

54-Cf.: 6, p. 66-72; 14, p. 111.

55-Acerca das diferenças e semelhanças entre a Dissertação e a Crítica, cf.: 27, p. 3-25; 56, p. 39-49.

$56-45$, p. 404; trad. p. 66.

$57-45$, p. 402 ; trad., p. 61.

58-45, p. 395; trad., p. 48.-Cf. 52, p. 320; 74, t. II, p. 26: "Le terme 'à l'ocasion de l'experience' vise tout le processus, qui débute par une impression et finit par la formation du schème, obligeant la forme générale de l'entendement a se contracter dans une des formes particulières du jugement."; 60, I. Bd. (1797), I. Abtheil, p. 1: "As impressões que recebemos dos sentidos podem ou meramente ser a ocasião (Veranlassung) de efetuar um conhecimento - de forma que por ocasião (bey Gelegenheit) dos mesmos obtenho um certo conhecimento - ou são efetivamente aquilo só de onde pode nascer (entstehen) o conhecimento".

59-Cf. 43, p. 258: "Adquiro algo quando faço (efficio) que algo se torne meu.-Originariamente (Ursprünglich) meu é aquilo de externo que mesmo sem um ato jurídico é meu. Uma aquisição originária, porém, é aquela que não é derivada do seu de um outro.

"Nada de externo é originariamente meu; mas pode ser originariamente adquirido, isto é, sem derivar do seu de algum outro."

$60-$ Cf. 73 , p. $104-5$. 
61-Cf.: 60, V. Bd. (1802), I. Abtheil, p. 183, Anm.: "| o| procedimento originário (ursprüngliche) da imaginação transcendental na conexão do estofo temporal (Zeitstoffs) ao tempo não pode, como todo o Originário (Ursprüngliche), ser mais esclarecido"; 60, IV. Bd. (1801), I. Abtheil, p. 20: "Kant descobriu que a faculdade de produzir representações, ou o entendimento (...) deve ter uma certa natureza originária (ursprüngliche Beschaffenheit), que, em todo o sujeito que tem um entendimento, existe antes de todo o pensamento efetivo, através do qual as representações do mesmo obtêm uma certa forma-intelectual ('Verstandes'form)"; acerca de Platão, ou da opinião de Kant sobre este, assim se expressa Mellin, cujo comentário é calcado em Tiedemann ("System der Platonischen Philosophie"; 4 Bände; Leipzig, 1792): 60, IV. Bd. (1802), II. Abtheil, p. 618-9: "Ele considerava as idéias como conceitos originários, inatos (als ursprüngliche, angebohrne Begriffe), que não podem ser esclarecidos a partir da função (atividade) da razão (aus der Funktion (Thätigkeit) der Vernunft), e que, portanto, são derivados da inteligência divina (da 'razão suprema')."

62-Cf. 38, p. 221-3: "A 'Crítica' não aceita, em absoluto, representações incriadas (anerschaffene) ou inatas (angeborne); pertençam à intuição ou aos conceitos do entendimento, ela as considera todas como adquiridas (erworben). Mas há também uma aquisição originária (urspnüngliche Erwerbung) (tal como se expressam os mestres do direito natural), conseqüentemente, também daquilo que antes não existia ainda de modo algum, por conseguinte, que não pertencia a coisa alguma antes dessa ação. Tal é, como afirma a 'Crítica', primeiramente a forma das coisas no espaço e no tempo, em segundo lugar a unidade sintética do múltiplo em conceitos; pois nenhum deles é tirado dos objetos por nossa faculdade de conhecimento, como dados em si mesmos neles, mas ocorre a priori a partir de si mesmo. Deve, porém, haver um fundamento (Grund) para isso no sujeito, que torne possível que as representações pensadas nasçam assim e não de outra maneira, e, além disso, possam ser referidas a objetos que ainda não estão dados, e ao menos esse fundamento é inato. (...) Esse primeiro fundamento formal, por exemplo, da possibilidade de uma intuição do espaço, só ele é inato, não a própria representação espacial; pois a faculdade de conhecimento sempre necessita de impressões para primeiro determinar a representação de um objeto (a qual sempre é uma ação própria). Assim se origina a intuição formal que se denomina espaço, como representação (da forma dos objetos externos em geral) originariamente adquirida, cujo fundamento, todavia (como mera receptividade), é inato, e cuja aquisição precede por largo tempo o conceito determinado de coisas correspondentes a esta forma; a aquisição dos últimos é acquisitio derivativa, à medida que já pressupõem conceitos gerais transcendentais do entendimento, que do mésmo modo não são inatos, mas adquiridos, cuja acquisitio, porém, como aquela do espaço, é, do mesmo modo, originaria, e nada pressupõe de inato senão as condições subjetivas da espontaneidade do pensamento (conformidade à unidade da apercepção)." (sobre a distinção entre "incriado" e "inato", cf.: 38, p. 222; 2-4: "(Visto que o próprio Sr. Eberhard observa que, para ser legítima a expressão incriado (anerschaffen), deve-se 
pressupor, já como provada, a existência de Deus, por que se serve ele da mesma (...) e não da velha expressão de inato?)") (Tetens também se referia às "representações fundamentais originárias" e às "derivadas"; cf., por exemplo: Bd. I, 71, p. 17; 23; 88); 46, p. 25: "- 'Lex originaria': Verstandesbegriff"; 41, A 216, B 263: "(...) und zwar zufolge jener ursprünglichen Gesetze (...)"; A 338, B 396: "(...) obgleich diese Idee ganz notwendig in der Vernunft nach ihren ursprünglichen Gesetzen erzeugt worden"); 37, p. 131: "(...) o Deus ex Machina é, na determinação da origem e da validade de nossos conhecimentos, o mais absurdo que se pode escolher, e, além do círculo vicioso no encadeamento de nossos conhecimentos, há ainda a desvantagem de que favorece todo capricho ou toda quimera devota ou sonhadora"; 41, B 145-6; B 40; A 32, B 48; A 41, B 58; A 43, B 60; B 169; A 268, B 324; A 414, B 438; A 66, B 91: "Seguiremos... os conceitos puros até seus primeiros germes (Keimen) e disposições (Anlagen) no entendimento humano, nos quais eles estão preparados (vorbereitet), até que por ocasião da experiência (bei Gelegenheit der Erfahrung) sejam enfim desenvolvidos (entwickelt), e, libertos das condições empíricas aderentes (anhängenden) a eles, apresentados em sua pureza pelo mesmo entendimento." (cf.: 71, Bd. I; p. 6, onde se encontram os termos "Keim" e "Anlage" - e, 71, p. 59-60, onde se emprega a expressão: "bey Gelegenheit der Erfahrung"; 74, t. II, p. 24-6); A 86, B 118; B 166-8-texto que constitui, salvo engano, a melhor referência, embora indireta, em toda a Crítica da Razão Pura, à negação do inatismo (cf.: 11, p. 102-3; 74, t. III, p. 270; 22 ("Präformationssystem").); 72, Bd. 2, p. 309; 51, (Nr. 4859); 74, t. II, p. 156-7; 54, p. 542; 54, p. 233-4; "(...) mesmo os conceitos do entendimento, embora não sejam derivados dos sentidos, originam-se (entspringen) todavia por ocasião da experiência (bei Gelegenheit der Erfahrung); por exemplo, ninguém teria o conceito de causa e efeito se não tivesse percebido causas através da experiência. (...) Mas por onde adentrá-los no entendimento? Não se deve admiti-los como incriados (anerschaffen) e inatos (angebohren), pois isso poria um fim a toda investigação, e é muito antifilosófico. (cf. 40, p. 138) Se eles são inatos, então são revelações. (cf. 41, B 408) (...) Mas os conceitos, segundo sua natureza, originam-se através do entendimento, por ocasião da experiência e dos sentidos, os quais não são derivados dos sentidos, mas da reflexão sobre os sentidos. (...) segundo a matéria, originam-se todos a partir dos sentidos; segundo a forma, a partir do entendimento, os quais conceitos não são porém inatos ao entendimento, mas nascem através de reflexão por ocasião da experiência. Exercitamos essa ação de reflexão tão logo temos impressões dos sentidos. Através do hábito essa reflexão tornou-se-nos familiar, de forma que não observamos que refletimos, e então achamos que tal fato reside na inatuição sensível." (cf. 41, A 303, B 359); 51, (Nr. 4473); p. 564; 51 (Nr. 4634); p. 617; 51 (Nr. 4851); p. 8: "Se os conceitos são meramente educta ou producta*.

"* (producta ou por influxo físico (empírico) ou por consciência da índole formal da nossa sensibilidade e entendimento por ocasião da experiência (bei Gelegenheit der Erfahrung), por conseguinte, producta a priori, não a posteriori). 
"A doutrina de ideis connatis conduz ao devaneio (Schwärmerei). Acqvisitae são acqvisitae a priori ou a posteriori - estas não são sempre intelectuais. (...)" 51 (Nr.: 4866; $4871 ; 4893 ; 4894 ;$ 5087); 47, p. 355; 44, p. 475-6; 40, p. 141; 73, p. 195; 60, III. Bd. (1800), I. Abtheil, p. 153: "Se nosso entendimento não tivesse a disposição inata (die angebohrne Anlage) de conectar o homogêneo através de uma rẹpresentação (grandeza), não poderíamos então coligir representações variadas como homogêneas sob um conceito ( $\mid$ sob | o predicado) e ter as representações a partir do âmbito do predicado sob o qual as representações são subsumidas no sujeito"; 7 . p. 96: "(...) despite his antipathy to the doctrine of innate ideas if taken literally, he $\mid$ Kant $\mid$ might be said to continue the tradition of Descartes and Leibniz in this respect ||"the existence of non-empirical concepts")|."

$63-41$, A 2.

64-Cf. 23, p. 165.

65-72, Bd. 1, p. 166.

$66-$ Cf. 72, p. 48.

67-72, Bd. 2, p. 99-100.

68-Cf. (Nr. 4900); p. 23: "Eu não me ocupo, como Tetens, com a evolução dos conceitos (todas as ações através das quais são produzidos os conceitos), nem, como Lambert, com a análise $\mid$ dos mesmos |, mas meramente com a | sua | validade objetiva. Eu não estou numa concorrência (Mitbewerbung) com esses homens."

69-Cf.: 72, Bd. 1, p. 167-8; 170-2; 175; 178; 183; Bd. 2, p. 90-1; 95; 100; 57, p. 373; 378; 426; 429 (p. 45; 70-1; 73-4; 76; 82-4; 91; 99-100; 108; 127-8; 415).

$70-11$, p. 1.

71-11, p. 87. - Cf. 11, p. 2-3.

$72-11$, p. 87.

73-11, p. 103.

74-Cf. 38, p. 221-2. 
$75-11$, p. 103.

76-Cf. 41, B 167.

$77-41$, B 167.

$78-41$, B 167.

$79-38$, p. 222.

80-11, p. 103.

81-41, B 1 (41, A 268-71, B 324-7).-Cf.: 41, A 1-acerca da "experiência" como "produto" do "entendimento", cf.: 41, A 97-8; A 86, B 118; B 127; 49, p. 316 (em contrapartida, cf.: 49, p. 300 , onde é dito que a "experiência" é o "produto dos sentidos e do entendimento"); 47, p. 275; 54, p. 232: "Os filósofos antigos, como Aristóteles, e depois dele os escolásticos, diziam que todos os nossos conceitos provêm dos sentidos, o que eles expressavam pela proposição: nihil est in intellectu, quod non antea fuerit in sensu. (...) A fim de conhecer e apreender de modo determinado quão amplamente pode ser aceita a proposição de Aristóteles, é preciso modificá-la um pouco e dizer: Nihil est quoad materiam in intellectu, quod non antea fuerit in sensu. Os sentidos devem dar-nos a matéria e o estofo, e esta matéria é elaborada pelo entendimento. No que tange àforma dos conceitos, ela é intelectual. A primeira fonte de conhecimento reside portanto na matéria que os sentidos of erecem. A segunda fonte de conhecimento reside na espontaneidade do entendimento"; 41, A 454, B 482 (Anm.): "Como condição formal da possibilidade das mudanças, o tempo, em verdade, precede objetivamente a estes, mas, subjetivamente e na efetividade da consciência, essa representação, assim como qualquer outra, só é dada por ocasião (durch Veranlassung) das percepções"; 72, Bd. 1, p. 165-6; 494-5; 60, III. Bd. (1801), II. Abtheil, p. 800: "Leibniz afirmava... com Platão: a alma contém originariamente os princípios de diferentes conceitos e conhecimentos que os objetos externos só na ocasião despertam. (nur bei Gelegenheit erwecken)*

"** A esse mote (Stelle) leibniziano, sem dúvida se refere aquela passagem (Stelle) (C.1): 'Nenhuma dúvida há de que todo o nosso conhecimento (...)"'; 60, IV. Bd. (1801), I. Abtheil, p. 14-5: "Kant descobriu o único verdadeiro sistema, e é por issoele próprio um líder (Haupt), a saber, o dos dualistas na teoria da origem do nosso conhecimento, ou daqueles que consideram o conhecimento como um composto (Zusammengesetzt), que, em parte se origina (entspringt) da razão, em parte da experiência (...)"; 11, p. 3-4: 
"Nessa proposição (cf. 41, B 1), a experiência é inserida como um enigma. A solução desse enigma é o conteúdo da filosofia kantiana.

\section{"Kant descobriu um novo conceito de experiência."}

"A 'Crítica da Razão Pura' é a crítica da experiência. Da exata certeza desse conceito de experiência depende se Kant, através de sua crítica, apaziguou as pretensões, tanto do ceticismo da empiria quanto do dogmatismo da razão pura, e com isso aplainou o conflito dos mesmos; pois, visto que de ambas as partes persistem direitos naturais, quando se tornam também erradamente vigentes, tal reconhecimento contém ao mesmo tempo essa proposição: o surgir (Anheben) é concedido ao ceticismo, o não-originar-se (Nichtenspringen) ao dogmatismo - como ambos se deixam reunir tem a ensinar o novo conceito de experiência." 11, p. 15-6;33-4;12, p. 8-9; 72, Bd.1, p. 178-9; 31, p. 55-6; 20, p. 325 e seguintes. - A propósito das formulações de Kant no início da "Introdução", cf.: 71, Bd. I, p. 336-7, por onde surge, ainda que só em nível da letra, uma coincidência espantosa entre os dois pensadores.

$82-41$, B IX.

$83-41$, A 847 , B 975.

84-41, B 73 ("Objekte möglicher Erfahrung"); B 148 ("Gegenstände möglicher Erfahrung").

85-41, B XVIII.-Cf.: 41; A 196, B 241; A 346-7, B 405: "(...) temos de atribuir necessariamente a priori às coisas todas as propriedades que constituem as condições sob as quais nós unicamente as pensamos."

86-Cf.: 41, A 104: o objeto é "aquilo... que é oposto (dasjenige... was dawider ist)"; A 105: "(...) conhecemos o objeto quando efetuamos a unidade sintética no múltiplo da intuição."

87-47, p. 275; "A tarefa suprema da filosofia transcendental é, portanto: como é possível a experiência?"-Cf.: 46, p. 24-5; 72, Bd. 1, p. 6: "Kant analisa a própria experiência na qual os empiristas tinham resolvido o saber. Posto que todo o nosso saber consiste de experiência, de que porém, pergunta Kant, consiste a própria experiência?"; 7.

88 -Cf.: 45 , § 7; 41, A 43-4, B 60-2; 49, p. 290; 35, p. 140-1; 47, p. 277; 46, p. 23; 54, p. 229-30; p. $240 ; 74$, t. I, p. $55-6 ; 65-70$. 
89 - Cf. 24, p. 202: "L'idéalisme critique s'accorde un donné pour être sûr de ne pas penser à vide, mais il prend aussitôt les mesures nécessaires pour que ce donné ne réserve jamais aucune surprise à la pensée qui l'accueille. Depuis l'instant même où il le réfracte dans les formes a priori de la sensibilité, jusqu'au moment où il l'organise en science grâce aux catégories de l'entendement,l'esprit jouit sans réserve du privilège d'exploiter un donné qui soit un réel, et qui ne contienne pourtant absolument rien que se qu'y met l'esprit."; 44, p. 472.

90-Cf.: 29, p. 87: "Kant encontra... pela primeira vez um conceito ontológico e não sensualista da sensibilidade"; 11, p. 15: "Na doutrina kantiana a sensibilidade vale como uma fonte de conhecimento. Essa proposição é um dos encaixes do sistema (...) Kant não parte da sensibilidade como de um princípio do qual deriva sua psicologia, mas do próprio processo (...) O processo significa aqui apenas a atividade do conhecimento. Kant partc desta, não de um órgão."

91 -Cf. 41, A 48, B 65: "Se não estivesse em nós uma faculdade de intuir a priori; se não fosse essa condição subjetiva, segundo a forma, ao mesmo tempo a condição universal a priori unicamente sob a qual o objeto desta própria intuição (externa) é possível (...)".

92-Cf. 42, p. 92: "Um conceito puro é tal que não é tirado da experiência, mas se origina, mesmo segundo o conteúdo, a partir do entendimento."

93-Cf. 41, A 94; A 115-6; 51 (Nr. 5644); p. 286: "(..) (o que a lógica é em referência a todo o conhecimento, tal é a filosofia transcendental em referência ao conhecimento puro a priori.)".-Cf. as judiciosas ponderações de: 26, p. 349-52.

94 -41, A 26, B 42. - Cf.: 41, B 67, onde a referência, ao contrário da anterior, que tratava do espaço, é agora o tempo; 41, A 31, B 47, onde, igualmente, a referência é o tempo: "Esses princípios | ("princípios apodíticos das relações de tempo") | valem como regras sob as quais em geral são possíveis experiências, e nos instruem antes das mesmas, e não por elas."

95-41, A 165, B 206: "A intuição empírica só é possível através da pura (do espaço e do tempo); portanto, o que a geometria diz desta vale incontestavelmente também para aquela, e os pretextos, como se os objetos dos sentidos não pudessem conformar-se às regras de construção no espaço (por exemplo: à infinita divisibilidade das linhas ou dos ângulos) tem de suprimir-se"; B 146-8; 49, p. 287-8. 
96-41, A 39, B 56: "Unicamente aqueles | (os fenômenos) | são o campo da sua |(espaço e tempo) | validade, de onde, em se saindo, nenhum outro uso objetivo dos mesmos tem lugar"; A 372-3: "(...) se se considera os fenômenos externos como representações que são efetuadas em nós por seus objetos como coisas que se encontram em si fora de nós, não se percebe como se poderia conhecer esta sua existência senão pelo raciocínio do ef eito à causa, no qual sempre há de permanecer duvidoso se a última está em nós ou fora de nós. Ora, pode-se em verdade assentir que algo de nossas intuições externas-que pode estar fora de nós no sentido transcendental-seja a causa, mas tal não é o objeto que compreendemos sob as representações da matéria das coisas corporais; pois estas são unicamente fenômenos, isto é, meros modos de representação que sempre se encontram em nós, e cuja efetivação, tanto quanto a consciência dos meus próprios pensamentos, repousa sobre a consciência imediata. $\mathrm{O}$ objeto transcendental, tanto em referência à intuição interna como à externa, é igualmente desconhecido. Mas também não é dele que se trata, mas do objeto empírico, que se chama um objeto externo se é representado no espaço, e um objeto interno se é representado unicamente em relações de tempo; porém, espaço e tempo são ambos encontrados apenas em nós"; 49, p. 288-90.

$97-38$, p. 221.

MARQUES, U.R. de A.-Kant et le problème de l'origine des reprèsentations elementaires: remarques. Trans/Form/Ação, São Paulo, 13: 41 - 72, 1990.

RÉSUMÉ: Il s'agit d'examiner l'origine des représentations fondamentales (formes de la réceptivité et formes intelectuelles) face à la critique faite par Kant des idées innées et abstraites.

UNITERMES: Acquisition originaire; acquisition derivative; "inné", "abstrait".

\section{REFERÊNCIAS BIBLIOGRÁFICAS}

1. AARON, R.I.John Locke. Oxford, Clarendon, 1973.

2. ARNAULD, A. \& NICOLE, P. La logique ou l'art de penser. Édition critique par P. Clair et F. Girbal. Paris, J. Vrin, 1981.

3. BALDWIN, J.M. (ed.) Dictionary of philosophy and psychology. New'Yurk, Macmillan, 1928.

4. BAUMGARTEN, A.G. Esthetique précédée des Méditations philosophiques sur quelques sujets se rapportant à l'essence du poème et de la Métaphysique. Traduction, présentation et notes par J.Y. Pranchère. Paris, L’Herne, 1988. 
5. BELAVAL, Y. Libres remarques sur le schématisme transcendental. In: L'HERITAGE de Kant; mélanges philosophiques offerts au P. Marcel Régnier. Paris, Beauchesne, 1982.

6. BERKELEY, G. Philosophical works: including the works on vision. Introduction and notes by M.R. Ayers. London, J.M. Dent, 1975.

7. BRANDT, R. Materialien zur Entstehung der Kritik der reinen Vernunft. In: HEIDEMANN, I. \& RITZEL, W, ed. Beitraege zur Kritik der reinen Vernunft 1781-1981. Berlin, Walter de Gruyter, 1981.

8. BRÉHIER, É. História da filosofia. Trad. E. Sucupira Filho. São Paulo, Mestre Jou, 1979.

9. CASSIRER, E. La filosofia de la ilustración. Trad. E. Imaz. México, Fondo de Cultura Económica, 1984.

10. CASSIRER, E. El problema del conocimiento. Trad. W. Roces. México, Fondo de Cultura Económica, 1986.

11. COHEN, H. Kants Theorie der Erfahrung. Berlin, Ferd. Duemmlers, 1871.

12. COHEN, H. Kommentar zu Immanuel Kants Kritik der reinen Vernunft. In: KANT, I. -Saemtliche Werke. Leipzig, Felix Meiner, s.d. (Supplement-Band).

13. COHEN, H. Logik der reinen Erkenntnis. In: HOLZHEY, H., dir. Werke; Herausgegeben vom Hermann-Cohen-Archiv am Philosophischen Seminar der Universitaet Zuerich unter der Leitung. von H. HOLZHEY. Hildesheim, Georg Olms, 1977.

14. CONDILlAC, E.B. de Lógica. Trad. N.A. Aguilar. São Paulo, Abril Cultural, 1979. (Os pensadores)

15. CONDILLAC, E.B. de. Tratado dos sistemas. Trad. L.R. Monzani. São Paulo, Abril Cultural, 1979. (Os pensadores)

16. DESCARTES, R. Ebtretien avec Burman. Texte présenté, traduit et annoté par C. Adam. Paris, J. Vrin, 1975.

17. DESCARTES, R. Lettre au Père Mersenne; 22 juillet 1641. In: Oeuvres philosophiques. Textes établis, présentés et annotés par F. Alquié. Paris, Garnier, 1967. V. 2

18. DESCARTES, R. Meditações. Trad. J. Guinsburg e B. Prado Jr. São Paulo, Abril Cultura, 1979. (Os pensadores).

19. DESCARTES, R. Notae in Programma. In: Qewvres philosophiques. Textes établis, présentés et annotés par F. Alquié. Paris, Garnier, 1973. v. 3. 
20. DILTHEY, W. De Leibniz a Goethe. Versión J. Gaos, W. Roces, J.Roura, E. Imaz. México, Fondo de Cultura Económica, 1945.

21. DUTENS, L. Origine des découvertes attribuées aux modernes. Paris, Chez la Veuve Duchesne, 1776. t. 1.

22. EISLER, R. Kant-Lexikon. Hildesheim, Georg Olms, 1984. (Praeformationssystem)

23. ERDMANN, B. Kant's Kriticismus in der ersten und in der zweiten Auflage der kritik der reinen Vernunft. Leipzig, Leopold Voss, 1878.

24. GILSON, É. L'être et l'essence. Paris, J. Vrin, 1981.

25. GILSON, É. L'innéisme cartésien et la théologie. In: Études sur le rôle de la pensée médiévale dans la formation du système cartésien. Paris, J. Vrin, 1930.

26. GRAYEFF, F. The relation of transcendental and formal logic. Kant-Studien, Berlin, 51(3): 349-52, 1959/1960.

27.GUEROVLT, M. La dissertation kantienne de 1770. Archives de Philosophie. Paris, 41: 3-25, 1978.

28. HAZARD, P. O pensamento europeu no séculoXVIII. Trad. G. Gabo. Lisboa, Presença, 1974.

29. HEIDEGGER, M. Kant et le problème de la métaphysique. Introduction et traduction par A. de Waelhens et W. Biemel. Paris, Gallimard, 1953.

30. HISSMANN. Bemerkungen über einige Regeln fuer den Geschichtschrei ber philosophischer Systeme; über Dutens Untersuchungen; und über die angebohrnen Begriffe des Plato, Descartes und Leibniz. Der Teutsche Merkur, Weimar, Viertes Vierteljahr: 22-52, 1777.

31. HOEFFE, O. Immanuel Kant. Versión de Diorki. Barcelona, Herder, 1986.

32. HUME, D. An abstract of a treatise of human nature. In: Abrégé du traité de la nature humaine. Texte original avec preséntation, traduction et notes par D. Deleule. Paris, Aubier Montaigne, 1971.

33. HUME, D. An enquiry concerning human understanding. Edited by L.A. Selby-Bigge. Oxford, Clarendon, 1957.

34. HUME, D. A treatise of human nature. Edited by L.A. Selby-Bigge. Oxford, Clarendon, 1967.

35. KANT, I. Anthropologie in pragmatischer Hinsicht. Akademie-Ausgabe. Berlin, Walter de Gruyter, 1968. 
36. KANT, I. Der einzige moegliche Beweisgnund fuereine Demonstration des Daseins Gottes. Akademie-Ausgabe. Berlin, Walter de Gruyter, 1968.

37. KANT, I. Briefwechsel. Akademie-Ausgabe. Berlin, Walter de Gruyter, 1968.

38. KANT, I. Über eine Entdeckung, nach der alle neue Kritikder reinen Vernunft durch eine aeltere entbehrlich gemacht werden soll. Akademie-Ausgabe. Berlin, Walter de Gruyter, 1968.

39. KANT, I. Grudlegung zur Metaphysik der Sitten. Akademie-Ausgabe. Berlin, Walter de Gruyter, 1968.

40. KANT, I. Kritik der praktischen Vernunft. Akademie-Ausgabe. Berlin, Walter de Gruyter, 1968.

41. KANT, I. Kritik der reinen Vernunft. Akademie-Ausgabe. Berlin, Walter de Gruyter, 1968.

42. KANT, I. Logik. Akademie-Ausgabe. Berlin Walter de Gruyter, 1968.

43. KANT, I. Die Metaphysik der Sitten. Akademie-Ausgabe. Berlin, Walter de Gruyter, 1968.

44. KANT, I. Metaphysische Anfangsgnuende der Naturwissenschaft. Akademie-Ausgabe. Berlin, Walter de Gruyter, 1968.

45. KANT, I. De mundi sensibilis atque intelligibilis forma et principio. Akademie-Ausgabe. Tradução adotada: Acerca da forma e dos princípios do mundo sensível e inteligível. Trad., apresentação e notas de L.R. dos Santos. Lisboa, Imprensa Nacional/Casa da Moeda/F.C.S.H. da Universidade de Lisboa, 1985.

46. KANT, I. Nachtraege zur Kritik der reinen Vernunft. 1. ed. Akademie-Ausgabe. Berlin, Walter de Gruyter, 1968.

47. KANT, I. Preisschrift über die Fortschritte der Metaphysik. Akademie-Ausgabe. Berlin, Walter de Gruyter, 1968.

48. KANT, I. Principiorum primorum cognitionis metaphysicae nova dilucidatio. Akademie-Ausgabe. Tradução adotada: Nouvelle explication des premiers principes de la connaissance métaphysique. Trad. J. Ferrari. In: Oeuvres philosophiques. Editi.

49. KANT, I. Prolegomena zu einer ieder kuenftigen Metaphysik, die als Wissenschaft wird auftreten koennen. Akademie-Ausgabe. Berlin, Walter de Gruyter, 1968.

50. KANT, I. Reflexionen zur Logik. Akademie-Ausgabe. Berlin, Walter de Gruyter, 1968. 
51. KANT, I. Reflexionen zur Metaphysik. Akademie-Ausgabe. Berlin, Walter de Gruyter, 1968.

52. KANT, I. Traeume eines Geistersehers, erlaeutert durch Traeume der Metaphysik. Akademie-Ausgabe. Berlin, Walter de Gruyter, 1968.

53. KANT, I. Versuch den Begriff der negativen Groessen in die Weltweisheit einzufuehren . Akademie-Ausgabe. Berlin, Walter de Gruyter, 1968.

54. KANT, I. Vorlesungen über Metaphysik. Akademie-Ausgabe. Berlin, Walter de Gruyter, 1968.

55. LAMBERT, J.H. Von Johann Heinrich Lambert: 13 oct. 1770. In: KANT, I. Briefwechsel. Akademie-Ausgabe. Berlin, Walter de Gruyter, 1968.v. 10, Brief 61.

56. LEBRUN, G. O aprof undamento da Dissertação de 1770 na Crítica da Razão Pura. In:__Kant. Brasília, 1981. p. 39-49. (Cadernos da UnB).

57. LEIBNIZ, G.W. Nouveaux essais sur l'entendement par l'auteur du système de l'harmonie prééstablie. In: GERHARDT, C.I., ed. Die philosophischen Schriften von Gottfried Wilhelm Leibniz. Hildesheim, Georg Olms, 1960. v.5.

58.LOCKE, J. An essay concerning human understanding. Edited by P.H. Nidditch. Oxford, Clarendon, 1988.

59. MEIER, G.F. Vernunftlehre. Apud: TONELLI, G. - Kant und die antiken Skeptiker. In: HEIMSOETH, H., HENRICH, D. \& TONELLI, G., eds. Studien zu Kants philosophischer Entwicklung. Hildesheim, Georg Olms, 1967.

60. MELLIN, G.S.A. Encyclopaedisches Woerterbuch der Kritischen Philosophie. Jena, Friedrich Frommann, 1797-1804. 6v.

61. MONTEIRO, J.P. Kant leitor de Hume, ou O bastardo da imaginação. Discurso, São Paulo, 14: 143-57, 1983.

62. PATON, H.J. Kant's metaphisic of experience. London, George Allen, 1970.

63. PITTE, F.P. Van de. Descartes et Kant; empirisme et innéité. Les Études Philosophiques, Paris, 2: 175-90, 1985.

64. RODIS-LEWIS, G. L'arrière-plan platonicien du débat sur les idées: De descartes a Leibniz. In: IDÉES et verités éternelles chez Descartes et ses successeurs. Paris, J. Vrin, 1985.

65. RODIS-LEWIS, G. L'inneité cartésienne et sa critique par Lelarge de Lignac. In: IDÉES et verités éternelles chez Descartes et ses successeurs. Paris, J. Vrin, 1985. 
66. ROED, W. Descartes dans la philosophie universitaire allemande du XVIII ${ }^{\mathrm{e}}$ siècle. Les Ėtudes Philosophiques, Paris, 2: 161-73, 1985.

67. RUSSEL, B. A filosofia de Leibniz. Trad. J.E.R. Villa-Lobos, H.L. de Barros e J.P. Monteiro. São Paulo, Ed. Nacional, 1968.

68. SANTOS, L.R. dos. Kant; Acerca da forma e dos princípios do mundo sensível e inteligível. Trad., apresentação e notas L.R. dos Santos. Lisboa, FC.S.H. da Universidade de Lisboa/Imprensa Nacional/Casa da Moeda, 1985.

69. SCHOPENHAUER, A. Crítica da filosofia kantiana. Trad. M.L.M. e O. Cacciola In: Schopenhauer. São Paulo, Abril Cultural, 1980. (Os pensadores).

70. STRAWSON, P.F. Los limites del sentido. Trad. C.T. Luis-André. Madrid, Revista de Occidente, 1975.

71. TETENS, J.N. Philosophische Versuche über die menschliche Natur und ihre Entwicklung. In: Die philosophischen Werke. Hildesheim, Georg Olms, 1979. v.1.

72. VAIHINGER, H. Kommentar zu Kants Kritik der reinen Vernunft. Neudruck der 2. Auflage. Aalen, Scientia, 1970.

73. VERNEAUX, R. Le vocabulaire de Kant. Paris, Aubier-Montaigne, 1967. (Doctrines et Méthodes).

74. VLEESCHAUWER, H.J. de. La déduction transcendantale dans l'oeuvre de Kant. In: BECK, L.W., ed. The philosophy of Immanuel Kant; a collection of eleven of the most important books on Kant's philosophy reprinted in 14 volumes. New York, Garland, 1976.

75. VUILLEMIN, J. Kant aujourd 'hui. In: CONGRÈS D'OTTAWA SUR KANT DANS LES TRADITIONS ANGLO-AMERICAINE ET CONTINENTALE, 10-14 oct. 1974. Actes... Ottawa, Université d'Ottawa, 1976.

76. VUILlEMIN, J. Physique et métaphysique kantiennes. Paris, P.U.F., 1987.

77. WALSH, W.H. Schematism. Kant-Studien, 49(1): 95-106, 1957-8.

78. WILLICH, A.F.M. Elements of the critical philosophy. In : WELLEK, R., ed. British philosophers and theologians of the $17^{\text {th }} \& 18^{\text {th }}$ centuries. New York, Garland, 1977. 